\title{
Impact of Climate on Vegetation Change in a Mountain Grassland - Succession and Fluctuation
}

\author{
Florin PĂCURAR ${ }^{1}$, Ioan ROTAR ${ }^{1 *}$, Albert REIF ${ }^{2}$, Roxana VIDICAN ${ }^{1}$, Vlad STOIAN ${ }^{1}$, \\ Stefanie M. GÄRTNER², Robert B. ALLEN ${ }^{3}$ \\ ${ }^{1}$ University of Agricultural Sciences and Veterinary Medicine Cluj-Napoca, Faculty of Agriculture, Calea Mănăstur 3-5, 400372 Cluj-Napoca, Romania; \\ fpacurar@gmail.com; ioan.rotar@usamvcluj.ro (*orrespondingauthor); roxana.vidican@usamvcluj.ro; vladh_stoian@yahoo.com \\ ${ }^{2}$ University of Freiburg, Faculty of Environment and Natural Resources, Tennenbacherstr. 4, 79085 Freiburg, \\ Germany; albert.reif@waldbau.uni-freiburg.de; stefanie.gaertner@waldbau.uni-freiburg.de \\ ${ }^{3}$ Landcare Research, P.O. Box 69040, Lincoln 7640, New Zealand; AllenR@landcareresearch.co.nz
}

\begin{abstract}
Traditionally managed Central European mountain grasslands have high nature conservation value because of their high species diversity. Whether these grasslands and their diversity can be preserved will depend on many factors, including how plant species composition responds to changes in climate conditions. To differentiate between fluctuations and directional succession in the herbaceous layer composition of a Romanian Festuca rubra L. and Agrostis capillaris L. grassland in Apuseni and whether any compositional changes can be related to climate. The vegetation of permanent plots was recorded annually between 2004 and 2012. Temperature and precipitation were measured by an automatic weather station at the study site. Cluster analysis, Indicator Species Analysis and the co-dominance ratio between F. rubra L. - A. capillaris were analysed. The compositional data was related to the climate variables. Thresholds of relevant climate variables differentiating between clusters of plots with similar vegetation composition were determined using classification tree methods. The vegetation composition in our plots within the years 2004, 2005 and 2008 were different from each other. From 2004 to 2006 directional succession could be identified; however the major patterns to emerge were fluctuations which occurred over the whole study period. Compositional shifts included A. capillaris L. and F. rubra L exchanging co-dominance with each other. The most important variables differentiating clusters were temperature during the dormant and vegetation periods and water balance during the vegetation period. It can be concluded that compositional shifts among years were largely a consequence of year to year climatic fluctuations; however, there is some evidence for a directional shift during the early years of the study.
\end{abstract}

Keywords: climate fluctuation, vegetation dynamic, Festuca rubra L. - Agrostis capillaris L. meadow, Romania

\section{Introduction}

Habitats with a long history have reached an equilibrium which is not static and fluctuates permanently by undirected changes of lesser magnitude (Frelich, 2002). Climate fluctuations also generate floristic, structural and functional changes in plant communities including grassland (Petrychenko et al., 2012). These climate introduced fluctuations were shown to occur in grasslands of North America (Collins et al., 1987), the Czech Republic (Dostálek and Frantík, 2011), Poland (Zarzycki and Szewczyk, 2013) and other areas (Cui, 2009; Egan and Crandall, 2008; Ihm et al., 2007; Lal, 2012, Miller, 2008; Schmer et al., 2010).

Successional trends are difficult to separate from fluctuations (Kasperek 1998, Matesanz et al., 2009). Changes of temperature and precipitation have caused well documented shifts in species composition, community structure and turnover of grassland vegetation (Deutsch et al., 2011; Heisler-White et al., 2009; Niu and Wan, 2008). The duration of these changes and their impact at the ecosystem level are still largely unknown (Zurek 2011, 2012). The existing knowledge is based on phytosociological studies (Brito et al., 2014; Leonard, 2014; Worthington, 2014), but experimental studies are lacking.

In an experimental approach site factors can be quantified and management can be simulated. The climate effect on the behaviour of plant species is less known (Niu and Wan, 2008). Understanding and quantifying the impacts of climate remains a key-challenge for ecologists (Heisler-White et al., 2009). Knowledge about the relationships between climate and vegetation is essential for planning land-use, retaining and enhancing biodiversity, and climatic change modelling (Morecroft et al., 2004; 
Plantureux et al., 2012; Sala et al., 2000; Schneider et al., 2009; Schaumberger, 2012; Trnka 2011).

Only long-term monitoring in multifactorial experiments exploring the interacting effects of land use change and climatic fluctuations can provide the necessary data to distinguish these processes, e.g., the impact of changing precipitation patterns (Morecroft et al., 2004). Only few studies exist and they are largely confined to systems with a capacity for rapid compositional change (e.g. Grime et al., 2008).

Mountain grasslands contain some of the most important high nature conservation value areas in Europe (Veen et al., 2009). Highly diverse mountain farmlands can increase tourism incomes and provide a potential seed source for local biodiversity restoration (Hopkins, 2011).

The interactions between climate and management in grasslands dominated by Festuca rubra L. and Agrostis capillaris L. seem to produce fluctuations in species abundance and cause changes in succession affecting the species composition, diversity and biomass production (Pleșa, 2012). Phytosociological studies rarely define robust community dynamics (Cristea et al., 2004).

The objectives of this study were to distinguish the successional trends and fluctuations in a Festuca rubra L. Agrostis capillaris L. grassland in the Apuseni Mountains, Romania in an experimental approach. Permanent sample plot data from Romanian mountain grassland were measured annually over nine years. Our aim was: (1) to quantify the long-term directional successional floristic changes under the impact of climate and management through mowing (2) to identify the most relevant climatic parameters affecting the species composition in the shortterm; (3) to develop a model of the grassland community response on the species-level, including the changes in $F$. rubra L. and A. capillaris L. co-dominance patterns.

\section{Materials and methods}

\section{Study area and experimental design}

The research was conducted near the village of Ghețari, Gîrda de Sus commune, situated in the central part of Apuseni Mountains, Romania (coordinates: latitude 46 $29^{\prime} 24.88^{\prime \prime}$ and longitude $\left.022^{\circ} 48^{\prime} 52.40^{\prime \prime}\right)$. The regional geology is dominated by limestone (Orășeanu, 2005). The area has a mountainous climate with an average temperature of $5.2^{\circ} \mathrm{C}$ and an average annual precipitation of $1122.65 \mathrm{~mm}$ (Plessa, 2012). The experiment was established in 2001 in a F. rubra L. $-A$. capillaris L. grassland, at $1130 \mathrm{~m}$ elevation on a red preluvosol soil with an average nitrogen content $(0,212 \%)$ but poor in phosphorus (3 ppm) and potassium (25 ppm) (Parichi and Stănilă, 2005). The vegetation was recorded on 16 plots, placed on a uniform phytocoenosis with a total area of $3000 \mathrm{~m}^{2}$, each plot having a size of $10 \mathrm{~m}^{2}$. Starting from 2001 plots were mowed each year when the grasses were in bloom. As a historical management, land surface was used in a mixed farming system during 1990-2000, through mowing and occasionally autumn grazing with cattle and horses. Therefore, the mowing regime was slightly adjusted as grazing did not occur every year.

\section{Assessment of climatic variables and calculation of indices}

An automatic weather station was set up in the research area, which recorded temperature and rainfall every 15 minutes. The climatic data was split into two periods: the vegetation period (May - October) and the dormant period between 20 of November and April (outside of vegetation period). For each period the monthly maximum and minimum temperatures were determined and the monthly precipitation totals were calculated. The combined effect of temperature and precipitation was incorporated into water balance and humidity indices. The soil water balance index was calculated as the difference between rainfall and evapotranspiration on a monthly basis (Vicente-Serrano et al., 2010). The potential evapotranspiration was estimated based on the simplified model proposed by Thornthwaite (1948) using R (R Core Team 2013) package "spei" (Begueria and Vicente-Serrano, 2013). The humidity index is a simplified expression of the ratio between monthly precipitation and potential evapotranspiration (Samaras, 2012).

Additionally, the climate conditions of the three previous years were analyzed regarding their impact on the vegetation composition change. In the following the climate variables were coded as follows: $\mathrm{t}$ - mean temperature ${ }^{\circ} \mathrm{C}, \mathrm{p}$ - rainfall sum, $w$ - water balance, $\mathrm{h}$ - humidity index, $\mathrm{m}$ - minimum value in a month, $\mathrm{M}-$ maximum value in a month, $\mathrm{v}-$ vegetation period, $o$ - outside the vegetation period or dormant period, 1 , 2,3 - the number of years ago.

\section{Vegetation data collection}

Vegetation data were collected through floristic relevés based on the cover abundance of each species using the BraunBlanquét scale (Braun-Blanquet, 1964). For greater precision, the scale's intermediate values were used (Gârda, 2010; Pleșa et al., 2010). Vegetation data from the permanent plots was collected from 2004 to 2012; on the period when the grasses were flowering. Therefore, for a better understanding, plots were placed in 2001, and vegetation data were collected annually from 2004 .

\section{Statistical analysis}

In the first step of the analysis sequence the plots were classified based on their species composition in order to understand and describe their similarity within and between the years. The hierarchical classification was performed using Soerensen index and the group average algorithm (agnes in the $\mathrm{R}$ "cluster" package, 1.14.4, Maechler et al., 2013) recommended by several authors (McCune et al., 2002; McCune and Mefford, 2011; Peck, 2010). Additionally, different dissimilarity indices and several algorithms were applied to ensure that the final solution was stable (Legendre and Legendre, 1998). The optimum number of clusters was confirmed by a multi-response permutation procedure (MRPP). This analysis (performed with PC-ORD ver. 6, McCune and Mefford, 2011) confirmed that there was a significant difference in species composition between the clusters.

In the next step the Indicator Species Analysis was used (Dufrêne and Legendre, 1997) to assess the degree to which a 
349

species indicates a compositional group based on its constancy and abundance (Tremp, 2005; Peck, 2010; Leyer and Wesche, 2007; Kent, 2012). This analysis was performed based on Soerensen index - using PC-ORD. For the interpretation, the Ellenberg indicator values adapted by Kovacs (1979) for Romania were used.

Additionally, the turnover between the two dominant species ( $F$. rubra L. and $A$. capillaris L.) was analysed with the co-dominance ratio (using Statistica 8.0, Statsoft, 2012). To analyse in detail the effect of the different climate variables on the abundance of the dominant species a comparative Post-hoc Fisher LSD type analysis was performed. This test emphasizes the significant differences among groups (Pleșa, 2012).

To examine variation in species composition we used unconstrained ordination (non-metric multidimensional scaling (NMDS) based on Soerensen index using metaMDS function ("vegan" package, Oksanen et al., 2013) and PC ORD. The latter was used to visualize vectors between the clusters in order to find out if a fluctuation or a succession happened and to determine the directional change in vegetation (McCune and Mefford, 2011). To quantify the general influence of the climatic variables (basic and synthetic) on the vegetation they were included in the non-metric multidimensional scaling (NMDS). The corresponding aligning of climatic factors to the ordination was performed using the function envfit ("vegan" package). Pearson-type correlations among species and climate variables, that were found amongst the climatic variables were analysed ("ecodist" package, Goslee and Urban, 2007). Prior to the NMDS, from each pair of strongly correlated climate variables, one was removed ( $r>0.80$, Chan, 2003) to reduce collinearity in the following analysis (Peralta et al., 2012).

To identify the climate thresholds between the different vegetation clusters the dataset was subdivided recursively into subsets using classification tree methods. These were increasingly homogeneous with respect to the defined groups, providing a tree-like classification and an associated dichotomous key to classify unknown samples into groups (Urban 2002). The calculations were performed using the "rpart" package (Therneau et al., 2013).

\section{Results and discussions}

\section{Vegetation classification}

The vegetation plots were divided into five clusters (Fig. 1). The results over nine years show that some years were floristically very homogenous while others were quite different. Especially the first and second year - 2004 (cluster 1) and 2005 (cluster 2) were different. Within the remaining large group, 2008 (cluster 4) forms another floristically different group while the other two comprise data from several years (clusters 3 and 5). This shows that the vegetation plots in some years were compositionally very similar to the same plots measured in other years, like 2006 to 2007 and 2010 (cluster 3) and 2009 to 2011 and 2012 (cluster 5).

During the nine year study period the sample plots fell into one of five distinctive composition (clusters) which largely represent temporal changes in the Festuca rubra L. - Agrostis capillaris L. grassland. The NMDS ordination showed that the five compositional groups formed through time are related to variability in temperature and precipitation as well as water balance and humidity indices.

The co-dominance ratio between $F$. rubra L. and $A$. capillaris L. changed during the nine years (Tab. 1). The cover of Agrostis capillaris L. decreased significantly during the study period from $24.27 \%$ (2004) to $10.47 \%$ (2009, 2011 and 2012). Contrariwise F. rubra L. showed an increasing trend from $15.72 \%$ cover (2004) to $23.17 \%$ (2009, 2011 and 2012).

\section{Fluctuation and successional trajectory}

The successional vectors in the ordination (Fig. 2) show that the plant community was transformed during the nine years due to climatic conditions. It seems that from '2004' (cluster 1) to '2005' (cluster 2) all four plots move along axis 1, with no change on axis 2 . Then from '2005' to '2006, 2007 and 2010 ' (cluster 3) all four plots move to lower scores on axis 1 but to higher scores on axis 2. Then from '2006, 2007 and 2010 ' to '2008' (cluster 4) plots move to slightly higher scores on axis 1 but barely move on axis 2 . The plots of cluster 5

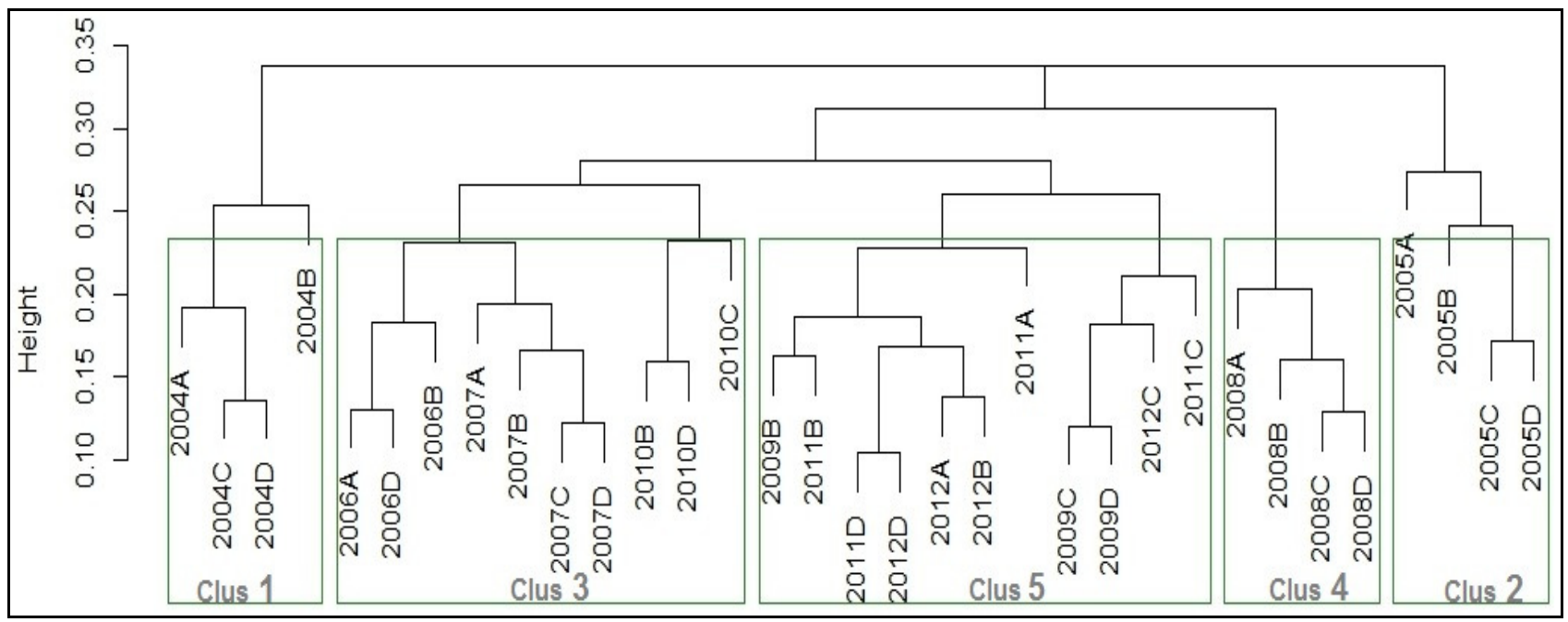

Fig. 1. Dendrogram showing the vegetation classification based on Soerensen index and the group average algorithm. A-D indicate the individual plots and 2004-2012 the year of assessment; Clus - cluster 
Tab. 1. Modification of co-dominance relationship between F. rubra L. and A. capillaris L. during 2004-2012, under the influence of climatic factors

\begin{tabular}{|c|c|c|c|c|c|c|}
\hline \multicolumn{7}{|c|}{ Agrostis capillaris L. } \\
\hline Cluster & & 1 & 2 & 3 & 4 & 5 \\
\hline & Cover $\%$ & 24.27 & 12.99 & 16.36 & 11.58 & 10.47 \\
\hline 1 & 24.27 & & $\mathrm{p}<0.001^{\circ 00}$ & $0.003^{\circ \circ}$ & $\mathrm{p}<0.001^{\circ 00}$ & $\mathrm{p}<0.001^{\circ 00}$ \\
\hline 2 & 12.99 & & & 0.120 & 0.574 & 0.197 \\
\hline 3 & 16.36 & & & & 0.063 & $0.004^{\circ 0}$ \\
\hline 4 & 11.58 & & & & & 0.632 \\
\hline 5 & 10.47 & & & & & \\
\hline \multicolumn{7}{|c|}{ Festuca rubra L. } \\
\hline Cluster & & 1 & 2 & 3 & 4 & 5 \\
\hline & Cover $\%$ & 15.72 & 16.44 & 19.67 & 24.17 & 23.17 \\
\hline 1 & 15.72 & & 0.859 & 0.338 & 0.075 & $0.043^{*}$ \\
\hline 2 & 16.44 & & & 0.358 & 0.067 & $0.027^{*}$ \\
\hline 3 & 19.67 & & & & 0.276 & 0.206 \\
\hline 4 & 24.17 & & & & & 0.905 \\
\hline 5 & 23.17 & & & & & \\
\hline \multicolumn{7}{|c|}{ Cluster: 1 - 2004; 2 - 2005; 3 - 2006, 2007, 2010; 4 - 2008; 5-2009, 2011, 2012} \\
\hline & & 5 & $\mathrm{p}<0.01$ & $\mathrm{p}<0.001$ & & \\
\hline
\end{tabular}

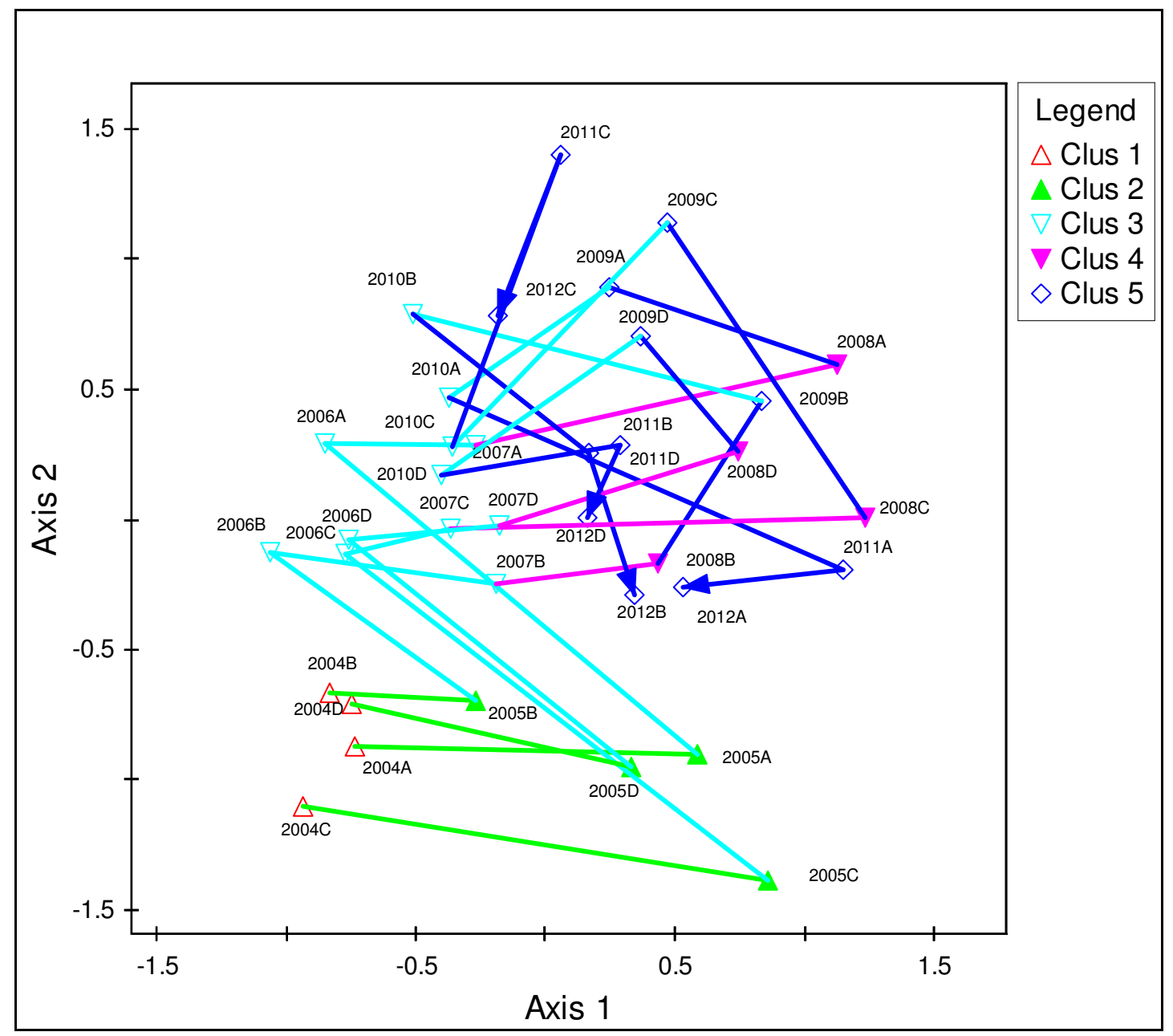

Fig. 2. Succession (trajectory) of the floristic composition during 2004-2012 plotted by succession vectors (clus1 - cluster 1, clus2 - cluster 2 , clus 3 - cluster 3 , clus 4 - cluster 4, clus 5 - cluster 5)

('2009, 2011 and 2012') are quite scattered in the NMDS ordination space. For this reason we will follow the cluster in segments and can say that from '2008' (cluster 4) to 2009 the plots move to a lower score on axis 1, but to a higher score on axis 2. The majority of the plots of clusters'2009, 2011 and 2012' remain almost at the same position on axis 1 and at a much lower position on axis 2 .
Climate caused obvious fluctuations and slight directional succession. During this floristic development the codominance ratio between $F$. rubra $\mathrm{L}$. and $A$. capillaris $\mathrm{L}$. often shifted. But the directional succession cannot be explained only by climate. Also, since 2001 (the year that the plots were established) the grassland management consisted in one mown/year. The combination of climate and management 
351
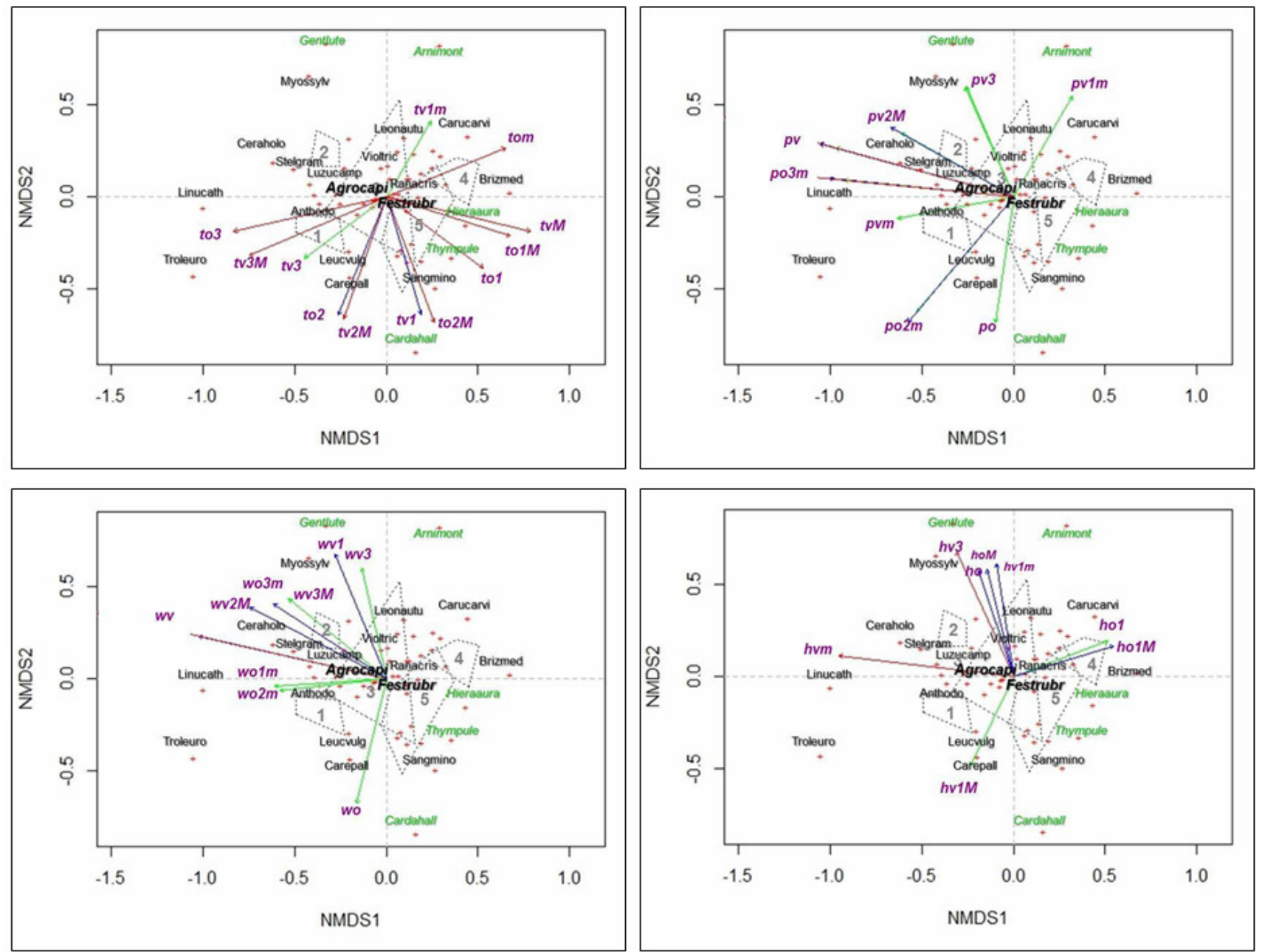

Fig. 3 ( $\mathrm{a}$ - upper left; $\mathrm{b}$ - upper right; c - bottom left; $\mathrm{d}$ - bottom right). Clusters ordination and influence of climatic parameters on vegetation: $\mathrm{a}$ ) mean temperature - $t, b)$ sum of precipitations $-p, c)$ water balance $-w, d)$ humidity index $-h(m-$ minimum value in a month, $M-$ maximum value in a month, $\mathrm{v}$ - vegetation period, $\mathrm{o}$ - outside the vegetation period, 1, 2, 3 - the number of previous years (their names' combinations codify the climate variables in the figure). The variables drawn in green show the $\mathrm{p}<0.05$, in blue $\mathrm{p}<0.01$, in red $\mathrm{p}<0.001$. The clusters are designed by figures from 1 to 5 drawn in grey. Dominant species: Agrocapi - Agrostis capillaris L., Festrubr - Festuca rubra L. Indicator species: Anthodo Anthoxanthum odoratum L., Brizmed - Briza media L., Carepall - Carex pallescens L., Carucarvi - Carum carvi L., Ceraholo - Cerastium holesteoides Fr.em.Hyl., Leonautu - Leontodon autumnalis L., Leucvulg - Leucanthemum vulgare Lam., Linucath - Linum catharticum L., Luzucamp - Luzula campestris L, Myossylv - Myosotis sylvatica Ehrh., Ranacris - Ranunculus acris L., Sangmino - Sanguisorba minor Scop., Stelgram - Stellaria graminea L., Troleuro - Trollius europaeus L., Violtric - Viola tricolor L. Margin species: Arnimont - Arnica montana L., Cardahall - Cardaminopsis halleri L, Gentlute - Gentianella lutescens Velen, Hieraaura - Hieracium aurantiacum L., Thympule - Thymus pulegioides $L$.

could have produced a change in vegetation or perhaps it was only one strong factor. In order to separate the effect of these factors, additional data are required which will be analyzed and discussed in a following paper. Collins et al. (1987) showed that stopping intensive grazing by goats can lead to an obvious successional trend. Based on our data from 2004-2012, a "dynamic equilibrium" (Cristea et al., 2004) in the F. rubra L. A. capillaris L. grassland appears to develop around the '20062007-2010' cluster (3) and the '2009-2011-2012'- cluster (5, except 2009). In these periods F. rubra L. occur as dominant and $A$. capillaris L. as subordinate. Coldea et al. (2012) and Frink (2010) have described the instability of the codominance of $F$. rubra L. and A. capillaris L. and our study confirms this. Coldea et al. (2012) concluded that the instability of the system is mainly due to the high nutrient content of the soil when $A$. capillaris L. prevails. Our study suggests these changes might be driven by climate fluctuations.

\section{The influence of climatic factors on the vegetation change}

The species composition of '2004' was positively related to higher temperatures occurring three years earlier (NMDS, Fig. 3a) while '2005' was influenced by higher water availability (Fig. 3bcd). '2008' is positioned opposite to the first two years and therefore also negatively related to their prevailing conditions. 
We could not identify species which had a specific ecological indicator value for 'temperature' or 'humidity', this suggests that the constancy and abundance of species reflects the complex action of the different climatic factors. For example, it is the combination of temperature and rainfall that is important for plant species' spreading (Wittig, 2012). In the mountains, differences among plant communities are the result of a complex of factors called "elevation complex" (Dierschke and Briemle (2002) and Höhenkomplex by Klapp (1971). This complex includes low temperature, long term snow cover, a short vegetative period, high precipitation, massive leaching through the soil profile, pronounced soil erosion, low biological activity in the soil and humus bioaccumulation (Dierschke and Briemle, 2002).

The first classification tree (Fig. 4) suggests that temperature variables play the main role in the floristic differentiation of the vegetation. An average temperature of less than $-1.3^{\circ} \mathrm{C}$ two years earlier during the dormant period (to2) separates the vegetation composition of cluster 1 and cluster 5 from the other vegetation clusters. On the next split (right side of the diagram) is indicated that if the minimum temperature during the vegetation period is less than $5.49^{\circ} \mathrm{C}$, the same probability exists to maintain the vegetation of cluster 1 or cluster 5 . On the left side, if the minimum temperature during the vegetation period in the previous year $(\mathrm{tv} 1 \mathrm{~m})$ was less than $5.49^{\circ} \mathrm{C}$, the vegetation as observed in the years ' 2006,2007 and 2010 ' (cluster 3) occurred by taking into account the temperature during the growing season of less than 4.6 the vegetation of clusters 2 or 4 will occur.

Influential for '2004' were the temperatures three years before as well as the precipitation in the current and the previous year which were higher than average. A high influence had also the temperature outside the vegetation period (recorded three years earlier; winter 2001/2002) which was much higher than the average during the rest of the study period. Niu and Shiqiang (2008), studying the effect of global warming on natural meadows in the temperate steppe of China, found that $A$. capillaris $\mathrm{L}$. became dominant under higher temperatures. The current year's minimum rainfall during the study period also plays an important role, and was almost twice the average in 2001-2012 (Annex 1). The findings

Tab. 2. Groups' indicator species ( $\mathrm{x}$ - indifferent species)

\begin{tabular}{|c|c|c|c|c|}
\hline Species & Indicator Value & Significance & Temperature Index & Moisture Index \\
\hline \multicolumn{5}{|c|}{ Cluster 1 (2004) } \\
\hline Anthoxanthum odoratum $\mathrm{L}$. & 49.3 & $0.0002^{* * *}$ & $\mathrm{x}$ & $\mathrm{x}$ \\
\hline Carexpallescens $\mathrm{L}$. & 45.0 & $0.0002^{* * *}$ & 4 & $x(6)^{*}$ \\
\hline Leucanthemum vulgare $\mathrm{L}$. & 58.5 & $0.0004^{* * *}$ & $\mathrm{x}$ & 4 \\
\hline Linum catharticum $\mathrm{L}$. & 44.9 & $0.0168 *$ & $\mathrm{x}$ & $\mathrm{x}$ \\
\hline Trollius europaeus L. & 75.0 & $0.0020^{* *}$ & 3 & 7 \\
\hline \multicolumn{5}{|c|}{ Cluster 2 (2005) } \\
\hline Luzula campestris $\mathrm{L}$. & 43.4 & $0.0004^{* * *}$ & $\mathrm{x}$ & 4 \\
\hline Cerastium holosteoides Fr. em. Hyl. & 56.6 & $0.0106 *$ & $\mathrm{x}$ & 5 \\
\hline Myosotis sylvatica Ehrh. ex Hoffm & 81.0 & $0.0008^{* * *}$ & $\mathrm{x}$ & 5 \\
\hline Stellaria graminea L. & 58.2 & $0.0006^{* * *}$ & $\mathrm{x}$ & 4 \\
\hline Viola tricolor $\mathrm{L}$. & 45.3 & $0.0260 *$ & 5 & $\mathrm{x}$ \\
\hline \multicolumn{5}{|c|}{ Cluster $3(2006,2007,2010)$} \\
\hline Leontodon autumnalis $\mathrm{L}$. & 57.6 & $0.0004^{* * *}$ & $\mathrm{x}$ & 5 \\
\hline \multicolumn{5}{|c|}{ Cluster 4 (2008) } \\
\hline Briza media $\mathrm{L}$. & 44.5 & $0.0272^{*}$ & $\mathrm{x}$ & $\mathrm{x}$ \\
\hline Carum carvi $\mathrm{L}$. & 60.1 & $0.0120 *$ & 4 & 5 \\
\hline Ranunculus acris $\mathrm{L}$. & 81.0 & $0.0394^{*}$ & $\mathrm{x}$ & $x(6)^{*}$ \\
\hline \multicolumn{5}{|c|}{ Cluster $5(2009,2011,2012)$} \\
\hline Sanguisorba minor Scop. & 41.7 & $0.0176^{*}$ & 6 & 4 \\
\hline
\end{tabular}

$\mathrm{x}$ - by Kovacz, 1979 and 6 - by Ellenberg, 1997

of the present study are partly consistent with those presented by Stampfli and Zeiter (2004), who found that in wet years $A$. capillaris L. and Anthoxanthum odoratum L. abundance increased in similar grassland types. The minimum water balance's influence in the dormant period was two years before 2004 , and it had a value in 2002 (wv2M) that was similar to the average during the study period, unlike the value registered in 2003 (wv2M) which was almost double the average for vegetation type observed in 2005. Maximum humidity during the vegetative period in '2003' influenced '2004' when it was almost triple than the average of 2001-2012 (Annex 1). Vegetation responses to extremes in the moisture regime are rapid and independent of annual rainfall (Heisler-White et al., 2009).

Considering the ecological indicator value for temperature and humidity (Tab. 2) only Trollius europaeus L. (according to the indicator value of Ellenberg et al., 1992) and Linum catharticum L. to a lesser degree showed the expected ecological indication in the present study. The presence of a generalist could be explained by climatic fluctuations which happened in the past. However, the ecological indication value might have to be adjusted based on measurements. For example, Leucanthemum vulgare L. prefers flooded conditions (Hölzel and Otte, 2003) and is diminished by cold winters (Nissinen, 2004). The vegetation composition in ' 2005 ' was influenced by rainfall during the vegetation period $(\mathrm{pv}=791.9 \mathrm{~mm})$, which was 20\% higher than the average during 2001-2012. Dostalek and Frantik (2011) recorded that the abundance of dicotyledonous species increased with rainfall in the Salabka Natural Reservation, Czech Republic. This result is consistent with our results for the Apuseni Mountains. Additionally, important for '2005' was the water balance during the vegetation period (wv) which was $80 \%$ higher than the average of the study period maximum water balance during the vegetation period in 2003 (wv2M), 62\% higher than the average during 2001-2012 (Annex 1). The minimum value of the humidity index during the vegetation period in 2005 (hvm) was double the average during 2001-2012, and the humidity index during the vegetation period in 2003 was $20 \%$ higher than average and had an important influence on the vegetation composition in cluster 2 (Annex 1 ). 
353

Based only on the synthetic climatic factors the second classification tree (Fig. 5) reveals that when the water balance was higher or equal to $135.2 \mathrm{~mm}$ during the vegetation period in the current year (WV) it was the most important factor, dividing roughly cluster 4 and 5 from the rest of clusters.

The minimum temperature during the dormant period (tom) had a strong influence for cluster 4 (2008), which was lower than the average obtained for 2001-2012 (Annex 1). The minimum rainfall in 2007 (pvlm) was particularly important as it was almost double the average (Annex 1). The value of the humidity index in the dormant period of 2007 (hol) had a strong influence and was $410.3 \%$ higher than the average during 2001-2012 while the maximum value of the humidity

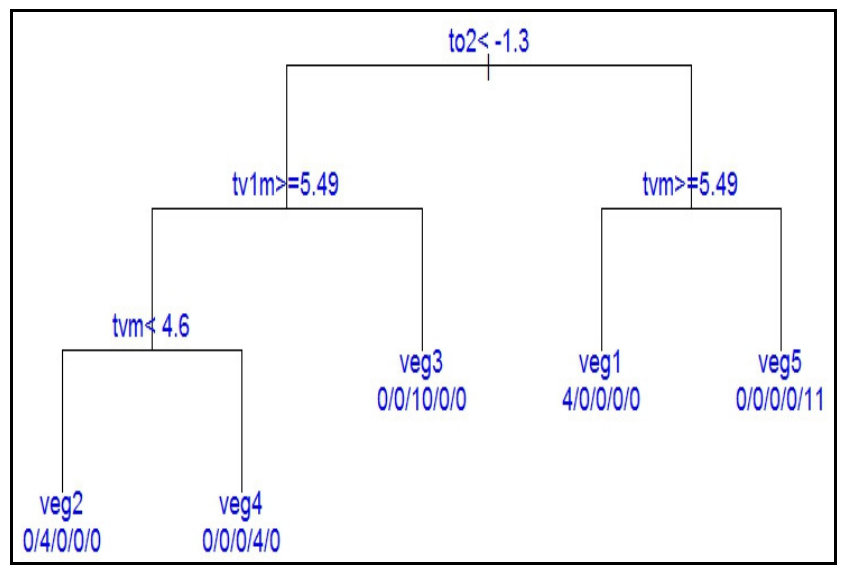

Fig. 4. Climatic factors with major importance to herbaceous layer changes (to2 - temperature of the vegetation period two years before, tvm - the temperature during the vegetation period in the current year, tv $1 \mathrm{~m}$ - the temperature during the vegetation period one year before, veg1 - cluster 1 (2004), veg2 - cluster 2 (2005), veg3 - cluster 3 (2006, 2007, 2010), veg4 cluster 4 (2008), veg 5 - cluster 5 (2009, 2011, 2012)

Cluster 5 (2009, 2011, 2012) was influenced by the maximum temperatures during the vegetation period (tvM) and the maximum temperatures in the dormant period one year before (to1M) and two years before (to2M, Annex 1). Rainfall in the dormant period (po) which, in general, was lower than the average during 2001-2012 also had an influence (Annex 1). Water balance in the dormant period, especially the current year's (wo) balance, which was generally lower than the average during the study period and had a similar influence (Annex 1). Overall, it is F. rubra L. as the dominant, $A$. capillaris L. as the co-dominant and Sanguisorba minor Scop. as an indicator that were determined first of all by the maximum temperatures both in the current year as well as in previous years and by lower rainfall in the dormant period of the current year. Our results are consistent with Stampfli and Zeiter (2004) who showed that $F$. rubra L. increased its abundance in drought years when compared with $A$. capillaris $\mathrm{L}$. which decreased in abundance. Those authors did not identify changes in Sanguisorba minor Scop. abundance after alternating periods of drought and rain.

The classification tree results emphasized that temperature in the dormant period two years before (to2) had the highest influence on changing the herbaceous layer when it was lower than index during the dormant period in 2007 (holM) was 418.9\% times higher than the average (Annex 1). Nowak and Sculz (2002) considered that $F$. rubra L. increased markedly after several rainy years, a result similar to our own. The preferences of the indicator species for temperature and rainfall do not correspond to the described situation and it can be asserted that the species' presence is determined mostly by the interaction between the previous year's temperature and humidity (humidity index). Stampfli and Zeiter (2004) have found that F. rubra L. increased in abundance with plentiful rainfall in previous years but average or even lower than average rainfall fell in the study year. They also found that Briza media L. decreased during drought, a result similar to the present study.

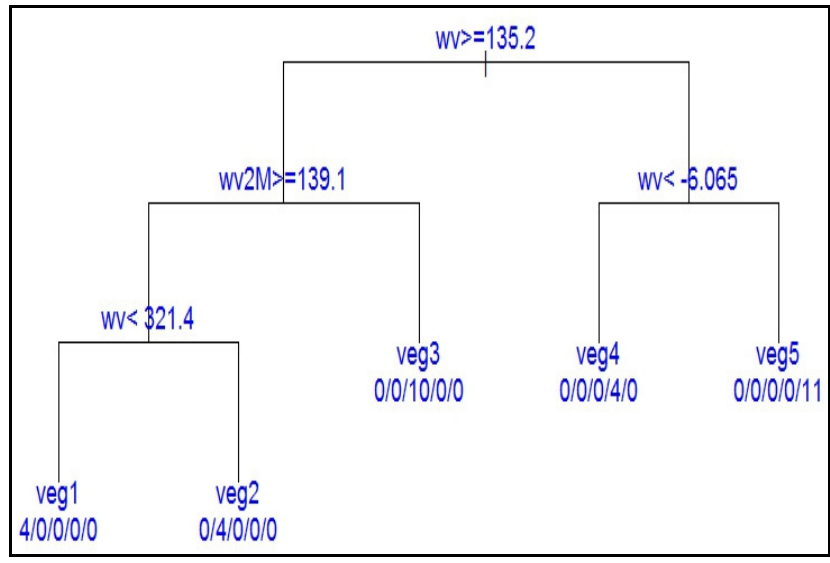

Fig. 5. The synthetic climatic indexes with major importance in herbaceous layer changes ( $\mathrm{wv}$ - water balance in the current year, wv2M - maximum water balance two years before, veg1 cluster 1 (2004), veg2 - cluster 2 (2005), veg3 - cluster 3 (2006, 2007, 2010), veg4 - cluster 4 (2008), veg5 - cluster 5 (2009, 2011, 2012)

$-1.3^{\circ} \mathrm{C}$. This, combined with the minimum temperature during the vegetation period one year before (higher or equal to $5.49^{\circ} \mathrm{C}$ ), resulted in a specific species composition.

Dostalek and Frantik (2011) studying the dry meadows in the Czech Republic stated that temperature had a lower effect on species abundance and richness compared to precipitation. It is somehow incongruous considering that the limiting factor in their study area is water. However, they found that the annual average temperature in the previous year had no effect upon the species abundance and species richness and only the temperature variation from one year to another played a significant role in the grass canopy changes. Similar to the findings of the present study they reported that the winter temperature considerably influenced the vegetation composition.

\section{Discussion}

The impact of climate during 12 years on the F. rubra L. A. capillaris $\mathrm{L}$. grassland has led to several alterations in the herbaceous composition which have occurred due to fluctuations and minimal succession. The co-dominance ratio between $F$. rubra $\mathrm{L}$. and $A$. capillaris $\mathrm{L}$. changes towards the dominance of $F$. rubra $\mathrm{L}$ at the end of the study 
period. The high amount of precipitation in the current year and the years before led to the dominance of $A$. capillaris L., whereas high temperatures and lower rainfall caused F. rubra L. to become the dominant species.

These results emphasize that precipitation and temperature during the last three years play an even greater role than the current year's precipitation and temperature regarding the grassland vegetation compositional changes. Extreme temperatures affect the herbaceous vegetation not only during the vegetation period but also in the dormant period.

The classification tree result has emphasized that the most important factor in fluctuations and succession on the herbaceous species composition was the temperature. The second most important factor in the fluctuations and succession of $F$. rubra L. - A capillaris L. plant community is the water balance during the current year. Experiments like ours, with long-term observations and equipped with weather stations can provide new information regarding the individual reactions of plant species as well as plant communities' responses to climatic fluctuations or climate changes. Furthermore, it is recommend to verify and to readapt the Ellenberg indicator values (originally adapted by Kovacs (1979) to the Romanian conditions) using up-todate technologies.

\section{Acknowledgments}

This paper was funded by the University of Agricultural Sciences and Veterinary Medicine Cluj-Napoca, the financing agreement 1363/8.02.2013.

\section{References}

Beguería S, Vicente-Serrano SM, (2013). SPEI: Calculation of the Standardised Precipitation-Evapotranspiration Index. R package version 1.6. http://CRAN.R-project.org/package=SPEI.

Braun-Blanquet J (1964). Pflanzensoziologie - Grundzüge der Vegetationskunde. Springer Verlag, Wien.

Brito JC, Godinho R, Martínez-Freiría F, Pleguezuelos JM, Rebelo H, Santos X, Vale CG, Velo-Antón G, Boratyński Z, Carvalho SB, Ferreira S, Gonçalves DV, Silva TL, Tarroso P, Campos JC, Leite JV, Nogueira J, Alvares F, Sillero N, Sow AS, Fahd S, Crochet PA, Carranza S (2014). Unravelling biodiversity, evolution and threats to conservation in the Sahara-Sahel. Biol Rev Camb Philos Soc 89(1):215-31.

Chan YH (2003). Biostatistics 104: correlational analysis. Singapore Med J 44(12):614-619.

Coldea G, Oprea A, Sârbu I, Sârbu C, Ștefan N (2012). Les associations vegetal de Romaine. Presa Universitară Clujeană, Cluj-Napoca.

Collins S, Bradford J, Sims P (1987). Succession and fluctuation in Artemisia dominanted grassland. Vegetatio 73:89-99.

Cristea V, Gafta D, Pedrotti F (2004). Fitosociologie. Ed. Presa Universitară Clujeană, Cluj-Napoca.

Cui X, Graf HF (2009). Recent land cover changes on the Tibetan Plateau: a review. Climatic Change 94(1-2):47-61.
Deutsch ES, Bork EW, Cahill JF, Chang SX (2011). Short-Term Plant Community Responses to Warming and Defoliation in a Northern Temperate Grassland. ISRN Ecology doi: $10.5402 / 2011 / 9260612011$.

Dierschke H, Briemle G, Kratochwil A (2002). Kulturgrasland: Wiesen, Weiden und verwandte Staudenfluren. E. Ulmer.

Dostálek J, Frantík T (2011). Response of dry grassland vegetation to fluctuations in weather conditions: a 9-year case study in Prague (Czech Republic). Biologia 66(5):837-847.

Dufrêne M, Legendre P (1997). Species assemblages and indicator species: the need for a flexible asymmetrical approach. Ecological Monographs 67(3):345-366.

Egan AN, Crandall KA (2008). Divergence and diversification in North American Psoraleeae (Fabaceae) due to climate change. BMC Biol 6:55.

Ellenberg H, Weber HE, Düll R, Wirth V, Werner W, Paulissen D (1992). Zeigerwerte von Pflanzen in Mitteleuropa. Verlag Erich Goltze KG, Göttingen.

Frelich LE (2002). Forest Dynamics and Disturbance Regimes: Studies from Temperate Evergreen-Deciduous Forests. Cambridge University Press, Cambridge.

Frink JP (2010). Pajiștile de pe valea Arieșului între Lupșa și Turda. Presa Universitară Clujeană, Cluj-Napoca.

Gârda N (2010). Studiul unor elemente de landșaft montan (cu privire specială asupra ecosistemelor de pajiști din comuna Gârda de Sus, Munții Apuseni). PhD thesis USAMV ClujNapoca.

Goslee SC, Urban DL (2007). The ecodist package for dissimilarity-based analysis of ecological data. Journal of Statistical Software 22(7):1-19.

Grime JP, Fridley JD, Askew AP, Thompson K, Hodgson JG, Bennett CR (2008). Long-term resistance to simulated climate change in an infertile grassland. Proceedings of the National Academy of Sciences 105(29):10028-10032.

Heisler-White JL, Blair JM, Kelly EF, Harmoney K, Knapp AK (2009). Contingent productivity responses to more extreme rainfall regimes across a grassland biome. Global Change Biology 15(12):2894-2904.

Hölzel N, Otte A (2003). Restoration of a species - rich flood meadow by topsoil removal and diaspore transfer with plant material. Applied Vegetation Science 6(2):131-140.

Hopkins A (2011). Mountainous farming in Europe. In: Pötsch EM, Krautzer B, Hopkins A. (Eds.). Grassland Farming and Land Management Systems in Mountainous Regions. Grassland Science in Europe 16:3-12.

Ihm BS, Lee JS, Kim JW, Kim JH (2007). Relationship between global warming and species richness of vascular plants. J Plant Biol 50:321-324.

Kasperek G (1998). Pflanzenökologische Untersuchungen im mittleren Rur-Tal (Nordrhein-Westfalen): Vegetation und Vegetationsdynamik unter besonderer Berücksichtigung von Fluktuationen in Dauerflächen. 344 S. (Archiv Naturwissenschaftlicher Dissertationen, Band 6.) MartinaGalunder-Verlag, Wiehl. 
355

Kent M (2012). Vegetation Description and Data Analysis: A Practical Approach (2nd Edition). John Wiley \& Sons.

Klapp E (1971). Wiesen und Weiden, eine Grünlndlehre. 4.Aufl., Parey, Berlin, Hamburg.

Kovacs JA (1979). Indicatorii biologici, ecologici și economici ai 563 florei pajiștilor. Ministerul Agriculturii și Industriei Alimentare. București.

Lal R (2012). Climate change and soil degradation mitigation by sustainable management of soils and other natural resources. Agric Res 1(3):199-212.

Legendre P Legendre L (1998). Numerical Ecology. Elsevier, Amsterdam.

Leonard M, Westra S, Phatak A, Lambert M, Hurk B, McInnes K, Risbey J, Schuster S, Jakob D, Stafford-Smith M (2014). A compound event framework for understanding extreme impacts. Wires Clim Change 5:113-128.

Leyer I, Wesche K (2007). Multivariate Statistik in der Ökologie: Eine Einführung. Springer-Verlag Berlin Heidelberg.

Maechler M, Rousseeuw P, Struyf A, Hubert M, Hornik K (2013). Cluster: Cluster Analysis Basics and Extensions. R package version 1.14.4. http://cran.rstudio.com/ web/packages/cluster.

Matesanz S, Brooker R, Valladares F, Klotz S (2009). Temporal dynamics of marginal steppic vegetation over a 26-year period of substantial environmental change., Journal of Vegetation Science 20:299-310

McCune B, Grace JB, Urban DL (2002). Analysis of ecological communities. 28. Gleneden Beach. OR: MjM software design.

McCune B, Mefford MJ (2011). PC-ORD. Multivariate Analysis of Ecological Data. Version 6. MJM Software. Gleneden Beach OR

Morecroft MD, Masters GJ, Brown VK, Clarke IP, Taylor ME, Whitehouse AT (2004). Changing precipitation patterns alter plant community dynamics and succession in an ex-arable grassland. Funct Ecol 18:648-655.

Miller W (2008). The Hierarchical Structure of Ecosystems: Connections to Evolution. Evo Edu Outreach 1:16-24.

Nissinen O (2004). Wild flower seed yields in northern Finland. Grassland Science in Europe 9:249-251.

Niu S, Shiqiang W (2008). Warming changes plant competitive hierarchy in a temperate steppe in northern China. Journal of Plant Ecology 1(2):103-110.

Niu S, Wan S (2008). Warming changes plant competitive hierarchy in a temperate steppe in northern China. Journal of Plant Ecology 2:103-110.

Nowak B, Schulz B (2002). Wiese, Nutzung, Vegetation, Biologie und Naturschutz am Beispiel der Wiesen des Südschwarzwaldes und Hochrheingebietes, Verlag Regionalkultur Heidelberg.

Oksanen J, Guillaume Blanchet F, Kindt Roeland, Legendre P, Minchin PR, O'Hara RB, Simpson GL, Solymos P, Stevens MHH, Helene Wagner (2013). Vegan: Community Ecology Package. $\mathrm{R}$ package version 2.0-9. http://CRAN.R606 project.org/package=vegan.
Orășeanu I (2005). Geomorphologie und Geologie des Höhenzuges zwieschen den Tälern von Gârda Seacă Ordâncusa. In: Rusdea E, Reif A, Povară I, Konold W. Perspektive für eine traditionelle Kulturlandschaft in Osteuropa, Culterra 35.

Parichi M, Stănilă L (2005). Böden der Gemarkung von Ghețari und angrenzender Gebiete. In: Rusdea E, Reif A, Povară I, Konold W. Perspektive für eine traditionelle Kulturlandschaft in Osteuropa, Culterra 35.

Peck JE (2010). Multivariate analysis for community ecologists: step-by-step using PC-ORD. MjM Software Design.

Peralta AL, Jeffrey WM, Diana NF, Angela DK (2012). Environmental Factors at Dissimilar Spatial Scales Influence Plant and Microbial Communities in Restored Wetlands. Wetlands 32(6):1125-1134.

Petrychenko V, Bohovin A, Kurhak V (2012). More efficient use of grassland under climate warming. Grassland Science in Europe 17.

Plantureux S, Michaud A, Baumont R (2012). Influence of pedoclimatic and management factors on botanical and functional composition of grasslands. Grassland Science in Europe 17.

Pleșa A, Păcurar F, Rotar I (2010). New direction with low-input of fertilization in grasslands. Bulletin of University of Agricultural Sciences and Veterinary Medicine Cluj-Napoca $67(1): 311$.

Pleșa A (2012). Cercetări privind folosirea și menșinerea pajiștilor montane cu low input. PhD thesis USAMV Cluj-Napoca.

R Core Team (2013). R: A language and environment for statistical computing. R Foundation for Statistical Computing, Vienna, Austria. URL http://www.Rproject.org/.

Sala OE, Chapin FS, Armesto JJ, Berlow E, Bloomfield J, Dirzo R, Huber-Sanwald E, Huenneke LF, Jackson RB, Kinzig A, Leemans R, Lodge DM, Mooney HA, Oesterheld M, Poff NL, Sykes MT, Walker BH, Walker M, Wall DH (2000). Global biodiversity scenarios for the year 2100. Science 287:1770-1774.

Samaras DA (2012). The vegetation of Greek fir (Abies cephalonica Loudon) forests on the Oxia-North Vardousia mountain system, central Greece, in relation to drought. Diss. Universität Freiburg, 2012.

Schaumberger A, Pötsch EM, Formayer H (2012). GIS-based analysis of spatio temporal variation of climatological growing season for Austria. Grassland Science in Europe 17.

Schmer MR, Mitchell RB, Vogel KP, Schacht WH, Marx DB (2010). Spatial and Temporal Effects on Switchgrass Stands and Yield in the Great Plains. Bioenerg Res 3:159-171.

Schneider RR, Hamann A, Farr D, Wang X, Boutin S (2009). Potential effects of climate change on ecosystem distribution in Alberta. Canadian Journal of Forest Research 39:10011010.

Stampfli A, Zeiter M (2004). Plant regeneration directs changes in grassland composition after extreme drought: a 13-year study 
in southern Switzerland. J Ecol 92:568-576.

Statsoft Inc. (2012). Electronic Statistics Textbook. Tulsa, ok:

Statsoft. Web: http://www.statsoft.com/textbook/.

Stevenson M, Peel S, Martin D (2005). Agri-environment

Schemes in England: identifying and targeting semi-natural grasslands for management and restoration. Grassland Science in Europe 10:158-172.

Therneau T, Atkinson B, Ripley B (2013). rpart: Recursive

Partitioning. $\mathrm{R}$ packageversion 4.1-3. http://CRAN.Rproject.org/package $=$ rpart.

Thornthwaite CW (1948). An Approach toward a Rational Classification of Climate, Geographical Review 38:55-94.

Tremp H (2005). Aufnahme und Ansalyse vegetation sökologischer Daten. Verlag Ulmer Stuttgart Eugen.

Trnka M, Bartošová L, Schaumberger A, Ruget F, Eitzinger J, Formayer H, Seguin B Olesen JE (2011). Climate change and impact on European grasslands. Grassland Science in Europe 16.

Urban DL (2002). Classification and regression trees, p 222-232. In: McCune B, Grace JB (Eds.). Analysis of ecological communities. MJM Software Design, Gleneden Beach, OR.
Veen P, Jefferson R, De Smidt J, Van Der Straaten J (2009). Grasslands in Europe of high nature value. KNNV Publishing, Zeist.

Vicente-Serrano SM, Beguería S, López-Moreno JI (2010). A multiscalar drought index sensitive to global warming: the standardized precipitation evapotranspiration index. Journal of Climate 23(7):1696-1718.

Wittig R (2012). Geobotanik. UTB Band-Nr.: 3753. Printed in Germany.

Worthington TA, Shannon KB, Timothy BG, Mueller J (2014). Backcasting the decline of a vulnerable Great Plains reproductive ecotype: identifying threats and conservation priorities. Global Change Biology 20:89-102.

Zarzycki J, Szewczyk W (2013). Impact of abandonment on the floristic composition of permanent grassland and grassland created on former arable land. Grassland Science in Europe 18:421-423.

Zurek G (2011). Effect of climate change on phenology of forage grass species. Journal of Life Sciences 5(9):754-758.

Zurek G (2012). Use of amenity grasses - status quo and innovations. Grassland Science in Europe 17.

Annex 1

\begin{tabular}{|c|c|c|c|c|c|c|c|c|c|c|c|c|c|c|c|c|c|}
\hline \multicolumn{18}{|c|}{ Individual and combined effect of climatic factors on grasslands phytocoenosys } \\
\hline \multicolumn{2}{|c|}{ Cluster } & Year & tvm & tvM & tv1 & tv1m & tv2m & tv2M & tv3 & tv3M & tom & to1 & to1M & to2 & to2M & to3 & to3M \\
\hline \multirow{10}{*}{ } & 1 & 2004 & 5.58 & 14.7 & 12.83 & 4.1 & 6.5 & 17.1 & 11.93 & 15.6 & -10.5 & -2.12 & 3.1 & 0.63 & 4.6 & -0.08 & 4.1 \\
\hline & 2 & 2005 & 3.6 & 14.8 & 10.59 & 5.58 & 4.1 & 16.3 & 12.33 & 17.1 & -9.4 & $-1,63$ & 4.7 & -2.12 & 3.1 & 0.63 & 4.6 \\
\hline & \multirow{3}{*}{3} & 2006 & 5.3 & 15.5 & 11.03 & 3.6 & 5.58 & 14.7 & 12.83 & 16.3 & -9.5 & -3.88 & 2.9 & -1.63 & 4.7 & -2.12 & 3.1 \\
\hline & & 2007 & 5.9 & 15.9 & 11.03 & 5.3 & 3.6 & 14.8 & 10.59 & 14.7 & -2 & -3.72 & 4 & -3.88 & 2.9 & -1.63 & 4.7 \\
\hline & & 2010 & 3.4 & 16.3 & 12.2 & 5.4 & 5.6 & 17.4 & 12.05 & 15.9 & -6 & -1.15 & 6.7 & -1.45 & 8.2 & 0.32 & 5.8 \\
\hline & 4 & 2008 & 5.6 & 17.4 & 12.05 & 5.9 & 5.3 & 15.5 & 11.03 & 14.8 & -5.1 & 0.32 & 5.8 & -3.72 & 4 & -3.88 & 2.9 \\
\hline & \multirow{3}{*}{5} & 2009 & 5.4 & 16.6 & 12.33 & 5.6 & 5.9 & 15.9 & 11.03 & 15.5 & -4.8 & -1.45 & 8.2 & 0.32 & 5.8 & -3.72 & 4 \\
\hline & & 2011 & 4.3 & 15.4 & 11.55 & 3.4 & 5.4 & 16.6 & 12.33 & 17.4 & -4.9 & -0.77 & 4.8 & -1.15 & 6.7 & $\begin{array}{l}-1.45 \\
\end{array}$ & 8.2 \\
\hline & & 2012 & 5.32 & 17.6 & 11.77 & 4.3 & 3.4 & 16.3 & 12.2 & 16.6 & -8.6 & -0.77 & 5.3 & -0.77 & 4.8 & -1.15 & 6.7 \\
\hline & & Mean & 4.93 & 16.02 & 11.71 & 4.80 & 5.04 & 16.07 & 11.81 & 15.99 & -6.76 & -1.69 & 5.06 & -1.53 & 4.98 & -1.45 & 4.90 \\
\hline \multicolumn{2}{|c|}{ Cluster } & Year & pv & pvm & pvM & pv1 & pv1m & pv1M & pv2m & pv2M & pv3 & pv3m & po & po1m & po2m & po3m & \\
\hline \multirow{10}{*}{ } & 1 & 2004 & 720.8 & 70.9 & 144.8 & 637.1 & 1.8 & 211.3 & 64 & 239 & 756.4 & 35.4 & 668.7 & 40.6 & 41.3 & 60.1 & \\
\hline & 2 & 2005 & 791.9 & 25 & 223.6 & 720.8 & 70.9 & 144.8 & 1.8 & 211.3 & 828.6 & 64 & 246.5 & 55.2 & 40.6 & 41.3 & \\
\hline & \multirow{3}{*}{3} & 2006 & 750.6 & 40.3 & 185.9 & 791.9 & 25 & 223.6 & 70.9 & 144.8 & 637.1 & 1.8 & 256.2 & 0 & 55.2 & 40.6 & \\
\hline & & 2007 & 669.2 & 79 & 158 & 750.6 & 40.3 & 185.9 & 25 & 223.6 & 720.8 & 70.9 & 372.4 & 5.4 & 0 & 55.2 & \\
\hline & & 2010 & 803 & 70.9 & 194.5 & $56+.4$ & 31.6 & 152.4 & 7.2 & 130.4 & 669.2 & 79 & 658.6 & 27.2 & 52.2 & 3.3 & \\
\hline & 4 & 2008 & 476.6 & 7.2 & 130.4 & 669.2 & 79 & 158 & 40.3 & 185.9 & 791.9 & 25 & 432.6 & 3.3 & 5.4 & 0 & \\
\hline & \multirow{4}{*}{5} & 2009 & 564.4 & 31.6 & 152.4 & 476.6 & 7.2 & 130.4 & 79 & 158 & 750.6 & 40.3 & 433 & 52.2 & 3.3 & 5.4 & \\
\hline & & 2011 & 468.6 & 14 & 235.6 & 803 & 70.9 & 194.5 & 31.6 & 152.4 & 476.6 & 7.2 & 271 & 72.8 & 27.2 & 52.2 & \\
\hline & & 2012 & 515.87 & 35.2 & 118.8 & 468.6 & 14 & 235.6 & 70.9 & 194.5 & 564.4 & 31.6 & 353.94 & 0.6 & 72.8 & 27.2 & \\
\hline & & Mean & 640.11 & 41.57 & 171.56 & 653.58 & 37.86 & 181.83 & 43.41 & 182.21 & 688.40 & 39.47 & 410.33 & 28.59 & 33.11 & 31.70 & \\
\hline \multicolumn{2}{|c|}{ Cluster } & Year & $\overline{w \mathbf{v}}$ & wvM & wv1 & wv2m & wv2M & wv3 & wv3M & wo & wo1m & wo2m & wo3m & & & & \\
\hline \multirow{10}{*}{ 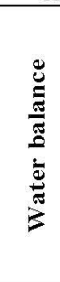 } & 1 & 2004 & 294.94 & 80.14 & 127.74 & -36.59 & 146.52 & 287.14 & 139.21 & 607.14 & 33.21 & 15.06 & 60.1 & & & & \\
\hline & 2 & 2005 & 347.94 & 131.59 & 294.94 & -103.37 & 180.63 & 339.01 & 146.52 & 266.27 & 45.1 & 33.21 & 15.06 & & & & \\
\hline & \multirow{3}{*}{3} & 2006 & 308.43 & 95.92 & 347.94 & 12.12 & 80.14 & 127.74 & 180.63 & 258.35 & 0 & 45.1 & 33.21 & & & & \\
\hline & & 2007 & 188.6 & 92.79 & 308.43 & 3.99 & 131.59 & 294.94 & 80.14 & 222.23 & 5.4 & 0 & 45.1 & & & & \\
\hline & & 2010 & 339.89 & 142.44 & 81.77 & -111.78 & 57.71 & 188.6 & 92.79 & 531.53 & -16.97 & 20.15 & -35.57 & & & & \\
\hline & 4 & 2008 & -13.76 & 57.71 & 188.6 & -19.57 & 95.92 & 347.94 & 131.59 & 408.45 & -35.57 & 5.4 & 0 & & & & \\
\hline & \multirow{3}{*}{5} & 2009 & 81.77 & 81.11 & -13.76 & -32.41 & 92.79 & 308.43 & 95.92 & 292.72 & 20.15 & -35.57 & 5.4 & & & & \\
\hline & & 2011 & 1.63 & 131.69 & 339.89 & -49.09 & 81.11 & -13.76 & 57.71 & 427.86 & 57.24 & -16.97 & 20.15 & & & & \\
\hline & & 2012 & 23.59 & 58.67 & 1.63 & -18.92 & 142.44 & 81.77 & 81.11 & 263.75 & -4.48 & 57.24 & -16.97 & & & & \\
\hline & & Mean & 174.78 & 96.90 & 186.35 & -39.51 & 112.09 & 217.98 & 111.74 & 364.26 & 11.56 & 13.74 & 14.05 & & & & \\
\hline \multicolumn{2}{|c|}{ Cluster } & Year & hvm & hvM & hv1m & hv1M & hv2m & hv2M & hv3 & hv3m & hv3M & ho & hoM & ho1 & ho1M & h02 & h02M \\
\hline \multirow{10}{*}{ 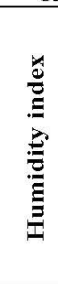 } & 1 & 2004 & 1.13 & 2.46 & 0.02 & 8.67 & 0.64 & 3.37 & 1.56 & 0.69 & 2.9 & 1.84 & 6.22 & 1.38 & 5.76 & 2.47 & 10.94 \\
\hline & 2 & 2005 & 1.05 & 2.44 & 1.13 & 2.46 & 0.02 & 8.67 & 1.97 & 0.64 & 3.37 & 6.64 & 34.13 & 1.84 & 6.22 & 1.38 & 5.76 \\
\hline & \multirow{3}{*}{3} & 2006 & 0.67 & 2.42 & 1.05 & 2.44 & 1.13 & 2.46 & 2.19 & 0.02 & 8.67 & 0.58 & 3.48 & 6.64 & 34.13 & 1.84 & 6.22 \\
\hline & & 2007 & 0.71 & 2.82 & 0.67 & 2.42 & 1.05 & 2.44 & 1.86 & 1.13 & 2.46 & 15.8 & 83.24 & 0.58 & 3.48 & 6.64 & 34.13 \\
\hline & & 2010 & 0.81 & 8.14 & 0.46 & 3.7 & 0.06 & 2.82 & 1.67 & 0.71 & 2.82 & 2.07 & 9.66 & 4.35 & 25.51 & 0.23 & 1.38 \\
\hline & 4 & 2008 & 0.06 & 2.82 & 0.71 & 2.82 & 0.67 & 2.42 & 1.66 & 1.05 & 2.44 & 0.23 & 1.38 & 15.8 & 83.24 & 0.58 & 3.48 \\
\hline & \multirow{4}{*}{5} & 2009 & 0.46 & 3.7 & 0.06 & 2.82 & 0.71 & 2.82 & 1.74 & 0.67 & 2.42 & 4.35 & 25.51 & 0.23 & 1.38 & \begin{tabular}{ll|}
15.8 \\
\end{tabular} & 83.24 \\
\hline & & 2011 & 0.19 & 2.27 & 0.81 & 8.14 & 0.46 & 3.7 & 1.33 & 0.06 & 2.82 & 1.72 & 9.45 & 2.07 & 9.66 & 4.35 & 25.51 \\
\hline & & 2012 & 0.34 & 2.98 & 0.19 & 2.27 & 0.81 & 8.14 & 1.43 & 0.46 & 3.7 & 0.57 & 3.42 & 1.72 & 9.45 & 2.07 & 9.66 \\
\hline & & Mean & 0.60 & 3.34 & 0.57 & 3.97 & 0.62 & 4.09 & 1.71 & 0.60 & 3.51 & 3.76 & 19.61 & 3.85 & 19.87 & 3.93 & 20.04 \\
\hline Inf & & & & & & & & n & & & & & & & & Combin & deffect \\
\hline
\end{tabular}

